\title{
Injectable Lipid Complex Dosage Form
}

National Cancer Institute

\section{Source}

National Cancer Institute. Injectable Lipid Complex Dosage Form. NCI Thesaurus. Code C42950.

A substance composed of complexed active and/or inert ing redient(s) with natural or synthetic lipids that is intended for injection. 